\title{
Modernisasi Sains Menuju Psikologi: Studi Atas Pengaruh Pemikiran Rene Descartes (1596-1650) Terhadap Perkembangan Psikologi
}

\author{
Abdul Rokhmat Sairah ${ }^{1}$ \\ ${ }^{1}$ Program Studi IImu Filsafat, Universitas Gadjah Mada, Yogyakarta, Indonesia \\ E-mail: rokhmat-sairah@ugm.ac.id ${ }^{1}$
}

\begin{abstract}
Abstrak
Psikologi ilmiah dewasa ini cenderung bersifat positivistik. Dominasi kaum behavioris pada beberapa dekade dalam fase perkembangan psikologi telah mereduksi makna disiplin ini. Psikologi seakan mengalami perubahan arah dalam perkembangannya. Oleh karena itu, diperlukan sebuah kajian untuk memahami hakekat psikologi. Langkah yang dapat ditempuh ialah dengan melacak kembali persoalan pokok dalam psikologi. Salah satu persoalan utama dalam psikologi adalah hubungan antara perilaku dan keadaan mental yang dalam sejarah pemikiran dicetuskan oleh Rene Descartes (1596-1650). la dipandang sebagai pionir sains modern karena meletakkan dasar-dasar penyelidikan ilmiah yang pada gilirannya berpengaruh dalam pengembangan psikologi. Penelitian ini bertujuan untuk mengungkap latar belakang historis psikologi dalam pemikiran Rene Descartes. Penelitian ini merupakan studi kepustakaan dengan menggunakan metode analisis hermeneutik kefilsafatan. Penelitian dilakukan dengan melacak kembali pemikiran Rene Descartes pada abad ke-17 M. Data berupa pemikiran Descates kemudian dianalisis melalui pemahaman secara kontekstual terhadap karakteristik psikologi saat ini. Hasil penelitian ini menemukan unsur-unsur pemikiran Rene Descartes yang berpengaruh dalam perkembangan psikologi antara lain konsep hubungan tubuh-pikiran, prinsip mekanisme dalam teori 'animal machine', dan fungsi-fungsi mental dalam diri manusia. Hal itu membuktikan bahwa kajian psikologi tidak melulu terbatas hanya pada perilaku manusia yang dapat diamati melalui observasi tetapi juga wilayah proses mental.
\end{abstract}

Kata kunci: Rene Descartes; psikologi; hubungan tubuh-pikiran.

Scientific psychology today tends to be positivistic. The dominance of behaviorism in several decades in the phase of psychology development has reduced the meaning of this discipline. Psychology had been changed direction its direction on proggress. Therefore we need a study to understand the essence of psychology. The way to consider this problem is back to the main problems of psychology. One of the main problems in psychology is the relationship between behavior and mental states which in the history of thought was coined by Rene Descartes (15961650). He was a pioneer of modern science because he laid the foundations for scientific inquiry which in turn influenced the development of psychology. This study aims to reveal the historical background of psychology in the Rene Descartes's thought. This research is a literature study using the hermeneutic method. The research conducted by exploring the thoughts of Rene Descartes in the 17th century AD. Data in this study is Descates's thoughts were then analyzed with a contextual understanding of the characteristics of current psychology. The results of this study found elements of Rene Descartes' thought that influence the development of psychology, including the body-mind relationship, the principle of mechanism in the "animal machine" theory, and humans mental functions. This proves that the psychology is not only limited to human behavior which observable but related to process of mental.

Keywords: Rene Descartes; psychology; mind-body relationship 


\section{Pendahuluan}

Psikologi merupakan salah satu ilmu yang mengalami perkembangan pesat akhir-akhir ini. Perkembangan psikologi mengarah pada kompleksitas persoalan, metodologi, dan model eksplanasi. Psikologi saat ini meliputi berbagai bidang yang tampaknya saling berbeda satu sama lain sehingga muncul berbagai sudut pandang (perspective) tentang apa itu psikologi. Berbagai sudut pandang tersebut tidak jarang saling klaim kehandalan metodologi dan teori sehingga berakibat pada terjadinya kompetisi untuk menjadi yang 'paling psikologi'. Tak dapat dipungkiri bahwa dalam perkembangan psikologi ada beberapa pandangan yang dominan, misalnya pandangan behaviorisme pada beberapa dekade abad ke-20. Psikologi ilmiah pada masa kontemporer mengindikasikan representasi karakter keilmiahan kalangan positivis, akan tetapi jauh sebelum psikologi menjadi seperti saat ini dasar-dasarnya telah diletakkan oleh para filsuf.

Persoalannya kemudian ialah apa yang melandasi bidang-bidang kajian menjadi bagian dari psikologi. Sesuatu yang menyatukannya adalah fokus penyelidikan terhadap hakikat dan tingkah laku manusia melalui pendekatan yang berupaya untuk menjadi ilmiah. Duane P. Schultz (2014: 2-3) menyatakan bahwa semua bidang dan pendekatan berbeda dalam psikologi disatukan oleh kerangka yang mengikat dan menjaga koherensi adalah sejarahnya yaitu evolusi psikologi sepanjang waktu sebagai sebuah disiplin ilmu. Oleh karena itu, diperlukan penyelidikan tentang sejarah dan filsafat psikologi untuk memahami hakikat psikologi yang dapat menjadi rujukan dalam memahami karakteristik psikologi sebagai sebuah bidang kajian maupun sebagai sebuah disiplin ilmiah,

Penyelidikan historis terhadap psikologi memberikan pemahaman tentang asal mula psikologi. Pemahaman itu diisi dengan apa dan bagaimana yang dikerjakan ilmuwan pada berbagai bidang dalam psikologi dari waktu ke waktu. Dari situ dapat diperoleh hal umum yang selalu ada dalam menjamin sifat dan karakter psikologi. Dengan demikian, dapat diperoleh gambaran yang utuh tentang perkembangan psikologi. Gambaran tersebut dapat dijadikan sketsa untuk merancang pola perkembangan psikologi yang pada gilirannya membantu dalam usaha evaluasi maupun perencanaan pengembangan psikologi.

Perkembangan psikologi dalam sejarahnya ditandai oleh beberapa momentum. Momentum itu berupa kemunculan gagasan yang bersifat filosofis yang menyita perrhatian sebagian besar penggiat di bidang yang terus mengalami perkembangan ini. Sehingga, tidak jarang arah perkembangan tidak melulu berupa garis lurus atau bersifat linear. Perkembangan justru dapat terjadi akibat perbedaan gagasan yang membangun diskursus. Akan tetapi perkembangan dapat juga terjadi akibat penajaman gagasan dari pemikir sebelumnya. Hal ini penting guna memahami pengaruh pemikiran dalam perkembangan psikologi.

Salah seorang tokoh penting yang meletakkan dasar-dasar psikologi modern adalah Rene Descartes (1596-1650). la menandai dimulainya era modern dalam penyelidikan ilmiah yang menjadi cikal bakal munculnya psikologi. Era modern ini berlangsung dari abad ke-17 sampai dengan abad ke-19 M. Descartes dikenal dengan pernyataannya, "Cogito, ergo sum", yang berarti, "Aku berpikir, jadi aku ada". Pendapat Descartes ini berarti bahwa landasan eksistensi manusia adalah berpikir (yang dalam arti luas dapat dipahami sebagai kesadaran). Pendapat ini merupakan batu loncatan dalam perkembangan psikologi karena mendorong ilmuwan dan pemikir lain berikutnya untuk membuktikan teori-teori yang dikemukakan dari pemikiran Rene Descartes.

Psikologi pada masa Descartes belum mapan sebagai ilmu yang mandiri, namun pondasinya telah mulai diperkuat sejak masa itu dan terutama ditandai oleh pemikiran-pemikiran yang dikemukakan oleh Rene Descartes. Psikologi kemudian muncul pada periode modern akhir yang ditandai dengan pendirian laboratorium eksperimen psikologi oleh Wilhelm Wundt pada tahun 1879 di Universitas Leipzig Jerman. Hal ini yang kemudian menjadi alasan bahwa psikologi tak dapat dipisahkan dari pengaruh pemikiran Rene Descartes. Oleh karena itu, penelitian ini diperlukan untuk mengidentifikasi karakteristik psikologi secara khusus dan perkembangan ilmu secara umum, sebagai bagian dari bidang kajian filsafat ilmu. 


\section{Metode Penelitian}

Metode penelitian ini adalah metode hermeneutika kefilsafatan. Penelitian ini menggunakan bahan atau materi dari studi literatur, sehingga penelitian ini merupakan penelitian pustaka. Data penelitian ini dibedakan menjadi dua yaitu data primer dan data sekunder. Data primer adalah sumber kepustakaan utama yang digunakan dalam penelitian, sedangkan data sekunder adalah literature pendukung yang digunkan untuk menunjang aktivitas penelitian (Kaelan, 2002: 18).

Data primer dalam penelitian ini adalah teks karya Duane P. Schultz dan Sidney Ellen Schultz, tahun 2014 berjudul A History of Modern Psychology terbitan Cengage Learning. Data primer lainnya diambil dari tulisan karya Gafry Hattfield yang berjudul Rationalist Roots of Modern Psychology (1977) dalam The Routledge Companion to Philosophy of Psychology yang diedit oleh John Symons dan Paco Calvo, terbitan Routledge. Teks ini berisi pemikiran kaum rasionalis tentang pikiran dan tindakan manusia dan sumbangannnya bagi perkembangan psikologi modern.

Data sekunder dalam penelitian ini adalah beberapa bacaan (literature) dari berbagai sumber yang berkaitan dengan perkembangan konsep dalam psikologi maupun tentang pemikiran Descartes. Data sekunder ini antara lain buku karya Matt Jarvis yang berjudul TeoriTeori Psikologi: Pendekatan Modern Untuk Memahami Perilaku, Perasaan, dan Pikiran Manusia (2000) yang diterbitkan oleh penerbit Nusa Media Bandung. Buku karangan Hilgard, Ernest, R. Richard C. Atkinson yang berjudul Introduction to Psychology (1957) yang diterbitkan oleh Harcourt, Brace \& World Inc. Buku ini membahas tentang perkembangan dan derivasi konsep dalam psikologi.

Penelitian ini dilakukan dalam beberapa tahap sebagai berikut.

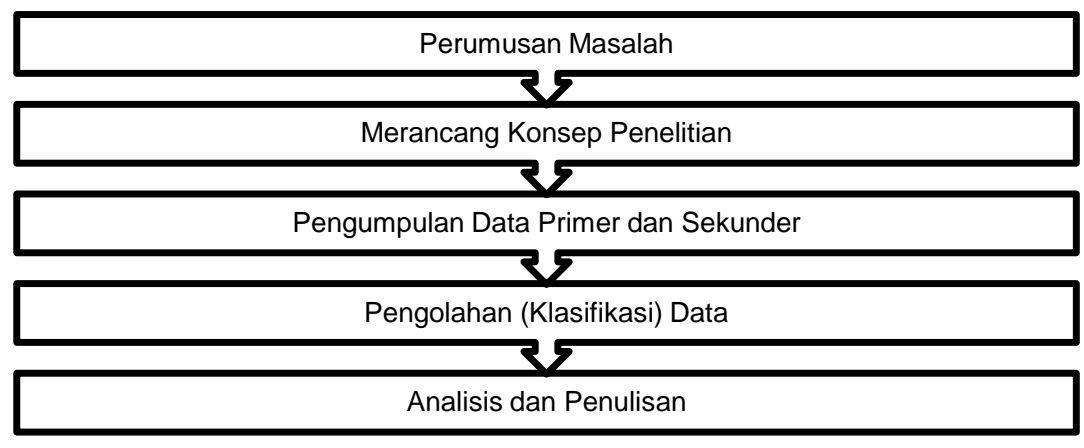

Analisis data penelitian ini menggunakan metode kualitatif bidang filsafat. Data yang diperoleh dianalisis dengan menggunakan perangkat metode kefilsafatan sebagai berikut:

a. Historis, data yang diperoleh dianalisis dengan melihat apakah memiliki kesenambungan historis atau tidak, maksudnya ialah melihat perkembangan perkembangan psikologi dengan pemikiran Descartes.

b. Interpretasi, data yang diperoleh dipahami dengan penafsiran untuk mengungkap arti dan nuansa yang dimaksud dari pemikiran kaum rasionalis dalam perkembangan konsep pada bidang psikologi.

c. Heuristika, data yang diperoleh dianalisis dengan mencari pemahaman baru tentang perkembangan psikologi khususnya psikologi kognitif berkaitan dengan berbagai konsep dalam pemikiran Rene Descartes tentang pikiran dan tindakan manusia.

d. Deskripsi, digunakan untuk menguraikan dan menjelaskan secara sistematis pemikiran Rene Descartes yang relevan dalam perkembangan psikologi.

\section{Hasil dan Pembahasan}

Penelitian ini mengandaikan dua hal pokok tentang hubungan antara pemikiran Descartes dengan psikologi. Pertama, ada unsur pemikiran Descartes tentang suatu hal yang kini menjadi bahan dan lapangan penyelidikan dalam psikologi. Kedua, ada karakteristik yang 
memberi corak dalam perkembangan teoretik dan bangunan pengetahuan psikologi modern dari pemikiran Descartes. Terlepas dari kedua hal di atas, tak dapat dipungkiri bahwa ada salah satu fase dalam perkembangan psikologi di mana pengetahuan masih terkonsentrasi pada penyelidikan tentang pengetahuan itu sendiri, masa di mana filsafat dan ilmu belum memiliki batas demarkasi yang tegas.

Fokus tulisan ini adalah pengaruh pemikiran Rene Descartes terhadap perkembangan psikologi, untuk itu perlu diuraikan karakteristik psikologi saat ini, perkembangan psikologi dalam perjalanan waktu, dan unsur-unsur pemikiran Rene Descartes yang terkait dengan psikologi dalam perkembangannya. Tiga hal tersebut begitu luas dan kompleks sehingga perlu batasan pembahasan. Pembatasan tersebut tentu mereduksi keseluruhan narasi. Akan tetapi pembahasan hasil penelitian di sini tidak mengurangi makna dari hal yang diuraikan dengan tidak menyimpang dari tujuannya.

\section{a. Psikologi Sebagai IImu di Era Kontemporer}

Istilah "psikologi" berasal dari bahasa Yunani dari kata "psyche" atau "psychē" yang berarti "jiwa"; dan kata " $\lambda$ óyos" atau "logos" yang berarti "pengetahuan" atau "ilmu". Jadi, psikologi secara harafiah dapat diartikan sebagai ilmu tentang jiwa (Weiten, 2017: 3). Istilah "psikologi" digunakan dalam terbitan karya ilmiah pertama kali pada abad ke-enam belas (Lapointe, 1972: 328). Buku pertama berjudul "Psychologia" ditulis oleh filsuf Skolastik Jerman Rudolf Goeckel (bahasa Latinnya Goclenius) pada tahun 1590 (Hatfield, 2009: 4). Buku itu masih berfokus pada pertanyaan teologis seperti apakah jiwa manusia ditiupkan oleh Tuhan ataukah diturunkan dari orang tua? Buku itu juga membahas topik-topik lainnya tentang kekuatan sensorik dan kognitif jiwa.

Istilah psikologi jarang digunakan di kalangan akademisi hingga awal abad ke-18, psikologi kemudian dikenal sebagai "studi tentang pikiran" (Weiten, 2017: 3). Istilah psikologi sebagai "ilmu jiwa" kemudian menjadi ilmu yang mempelajari perilaku sejak 1913 dipelopori oleh J.B Watson karena tuntutan pada masa itu terhadap ilmu untuk memiliki objek yang dapat diamati, dapat dicatat, dan dapat diukur (Jahja, 2011: 2). Jiwa dianggap terlalu abstrak dan hanya salah satu aspek kehidupan individu.

Psikologi pada era kontemporer diakui sebagai salah satu ilmu. Jahja (2011: 2) menyatakan bahwa psikologi menjadi ilmu yang mandiri karena memenuhi syarat yaitu: (1) psikologi dipelajari secara sistematis melalui penelitian-penelitian ilmiah dengan menggunakan metode ilmiah. (2) Psikologi memiliki struktur keilmuan yang jelas. (3) Psikologi memiliki objek material dan objek formal. (4) Psikologi menggunakan metode ilmiah seperti eksperimen, observasi, studi sejarah (case history), pengujian (test), dan pengukuran (measurement). (5) Psikologi memiliki terminologi khusus seperti bakat, motivasi, inteligensi, kepribadian. (6) Psikologi dapat diaplikasikan dalam berbagai bidang kehidupan.

Psikologi sebagai ilmu memenuhi ciri-ciri ilmu secara umum. Ciri-ciri ilmu menurut Van Melsen (1982) antara lain yaitu: (1) Metodis, artinya ilmu mengandung langkah-langkah yang ketat dan sistematis. (2) Tanpa pamrih, yaitu ilmu melepaskan diri dari kepentingan-kepentingan. (3) Universal, berarti bahwa ilmu dapat berlaku dalam seluruh ruang dan waktu. (4) Objektif, ilmu berorientasi untuk mengungkap kenyataan objeknya dan tidak dicampuri dengan prasangkaprasangka subjek. (5) Intersubjektif, artinya kebenaran ilmu tidak bersifat personal tetapi harus disepakati oleh komunitas ilmiah. Hal itu artinya ilmu harus dapat dikomunikasikan. (6) Progresif, ilmu selalu terbuka bagi perkembangan dengan menimbulkan problem-problem baru. (7) Kritis, artinya ilmu tidak definitif tetapi memiliki celah untuk peningkatan. (8) Pragmatis, ilmu harus mengandung keterkaitan antara teori dan praktek.

Ciri lain yang menandai ilmu terletak pada tujuannya. Donny Gahral Ardian dan Akhyar Lubis (2011: 22) menyatakan bahwa tujuan pengetahuan ilmiah adalah: (1) Deskripsi yaitu menjelaskan gejala-gejala. (2) Eksplanasi ialah tujuan ilmu untuk menjelaskan hubungan kausal (sebab-akibat). (3) Prediksi, tujuan ilmu untuk menggambarkan situasi tertentu di masa mendatang dari data yang diperoleh.

Psikologi sebagai disiplin ilmu akademik dan terapan melibatkan penelitian ilmiah atas proses mental dan perilaku. Psikologi mempelajari fenomena seperti: persepsi, kognisi, emosi, kepribadian, perilaku, dan hubungan antarpribadi. Psikologi juga mengacu kepada penerapan pengetahuan untuk berbagai bidang aktivitas manusia, yang berkaitan dengan masalah 
kehidupan sehari-hari seperti: keluarga, pendidikan, dan pekerjaan. Psikologi juga menangani persoalan kesehatan mental.

Psikologi sebagai ilmu sosial berusaha untuk memahami peranan perilaku manusia di dalam dinamika sosial seperti kebudayaan, ekonomi, dan politik. Psikologi dewasa ini juga menggabungkan proses psikologis dan neurologis ke dalam konsep tentang fungsi mental, meskipun berbeda dengan biologi dan neuroscience sebagai ilmu. Psikologi mencakup banyak sub-bidang studi dan aplikasi yang berkaitan dengan bidang-bidang seperti: perkembangan manusia, olah raga, kesehatan, industri, forensik, dan spiritualitas.

\section{b. Sejarah Singkat Perkembangan Psikologi}

Psikologi dalam perkembangannya banyak dipengaruhi oleh ilmu-ilmu lain misalnya Filsafat, Biologi, Fisiologi, Sosiologi, Antropologi (Jahja, 2011: 3). Ilmu-ilmu tersebut berpengaruh terhadap psikologi dengan meletakkan landasan epistemologis berupa kriteria hubungan subjek dan objek, metode yang digunakan, serta lingkup penyelidikan. Weiten (2017:3) mempertegas bahwa induk psikologi adalah filsafat dan fisiologi. Beberapa akademisi dari kedua bidang tersebut secara aktif mengeksplorasi persoalan tentang pikiran pada tahun 1870-an sampai seorang Professor Jerman bernama Wilhelm Wundt (1832-1920) kemudian mengkampanyekan psikologi untuk menjadi sebuah disiplin sendiri terlepas dari fisiologi dan filsafat.

Wilhelm Wundt berhasil mendirikan laboratorium resmi pertama untuk penelitian psikologi di Universitas Leipzig pada tahun 1879 (Weiten 2017: 3). Pengakuan atas momentum penting ini membuat sejarawan menandai peristiwa tersebut sebagai hari jadi psikologi. Wundt kemudian berhasil menerbitkan jurnal yang pertama kali membahas tentang metode penelitian dalam psikologi pada tahun 1881. Hal itu yang menjadikan Wilhelm Wundt kemudian dikenal sebagai "Bapak Psikologi".

Karya Wundt tak lama berselang kemudian disusul berbagai karya lainnya untuk meneguhkan posisi psikologi sebagai ilmu seperti saat ini. Filsuf Amerika William James (18241910) menerbitkan buku penting yang berjudul "Principles of Psychology" pada tahun 1890 yang memberi dasar bagi banyak persoalan yang menjadi pusat perhatian para psikolog di kemudian hari. Kontributor penting lain untuk psikologi pada permulaan menjadi ilmu yang positif dan empirisa adalah Hermann Ebbinghaus (1850-1909) sebagai pionir dalam bidang studi eksperimental terhadap memori di Universitas Berlin. Ivan Pavlov (1849-1936) dari Rusia menyelidiki proses belajar yang kini diacu sebagai proses belajar bersyarat klasik (classical conditioning).

Sigmund Freud (1856-1939), seorang dokter Austria yang tidak memiliki pendidikan formal di dalam psikologi eksperimental, mengembangkan metode psikoterapi yang dikenal dengan psikoanalisis pada tahun 1895. Pemahaman Freud tentang jiwa didasarkan atas metode interpretif (pemahaman atas makna sesuatu) dan introspeksi, dan memusatkan perhatian terutama pada pengatasan tekanan mental dan psikopatologi (penyakit mental).

Kemunculan psikologi selain dipengaruhi oleh berbagai latar belakang penyelidikan ilmuilmu juga dipengaruhi oleh beberapa pandangan filosofis yang beraneka ragam. Schultz (2014: 56) menyatakan bahwa landasan filosofis psikologi baru adalah positivisme, materialisme dan empirisisme. Positivisme adalah doktrin yang mengakui hanya fenomena yang dapat diobservasi secara objektif (Schultz, 2014: 55). Istilah positivisme digagas oleh seorang filsuf Prancis Auguste Comte (1798-1857) yang mewarnai corak pemikiran di Eropa pada pertengahan abad ke-19 M. Comte meyakini bahwa ilmu tidak tergantung pada kekuatan-kekuatan yang tidak dapat diamati atau keyakinan-keyakinan religius untuk menjelaskan fenomena alamiah.

Pendekatan positivistik mengacu pada sebuah sistem yang secara eksklusif didasarkan pada fakta-fakta yang dapat diobservasi secara objektif, dapat diamati, dan tidak dapat dibantah. Segala hal yang bersifat metafisik, spekulatif, inferensial dinyatakan sebagai ilusi atau ditolak. Kaelan dalam pengantar buku Mohammad Muslih (2016: vii) menyatakan bahwa berdasarkan prinsip-prinsip positivisme logis berkembang metode ilmiah yang didasarkan atas logika dan matematika yang dikenal dengan metode kuantitatif.

Pandangan filosofis yang mendukung positivisme adalah materialisme. Paham ini menyatakan bahwa fakta di alam semesta dapat digambarkan dalam istilah-istilah fisik dan dijelaskan dengan properti-properti benda dan energi (Schultz, 2014: 56). Pengaruhnya dalam 
psikologi berupa pandangan bahwa kesadaran manusia dapat dipahami dengan prinsip-prinsip fisika dan kimia. Proses-proses mental dapat dianalisis dengan fokus terhadap dimensi kebendaan yaitu struktur anatomis dan fisiologis otak.

Gagasan filosofis lainnya yang mempengaruhi kemunculan psikologi adalah empirisisme. Gagasan ini berpendapat bahwa semua pengetahuan dibangun dari pengalaman indrawi (Schultz, 2014: 56). Empirisis berpandangan bahwa pengalaman indrawi terakumulasi secara progresif disertai perkembangan pikiran sehingga gagasan empirisisme dapat dikaitkan dengan perkembangan pikiran. Beberapa pemikir yang tergolong empirisis di antaranya Jhon Locke (1632-1704), George Berkeley (1685-1753), David Hume (1711-1776), David Hartley (17051757), James Mill (1773-1836), Jhon Stuart Mill (1773-1836).

Gagasan empirisis merupakan respon terhadap pemikiran kaum rasionalis yang telah lebih dahulu merebut pengaruh melalui salah satu tokoh utamanya Rene Descartes. Gagasan empirisis tentang perkembangan pikiran belawanan dengan gagasan Descartes yang berpandangan nativistik. Descartes beranggapan bahwa beberapa ide atau gagasan itu bersifat bawaan (Schultz, 2014: 56). Gagasan Descartes telah mempengaruhi pandangan dunia tentang sains modern dua ratus tahun sebelum Comte mengemukakan gagasan positivisme.

Descartes membuat kontribusi besar dalam bidang filsafat dan ilmu meskipun telah ada tokoh empiris pendahulu dan sezaman dengannya yang terkenal dan berpengaruh (Raymond, 2009: 22). Tokoh tersebut antara lain Francis Bacon (1561-1626), Pierre Gassendi (1592-1655), dan Thomas Hobbes (1588-1679). Namun, rasionalisme Descartes yang dibayangi empirisisme zamannya menyediakan kerangka kerja bagi filsafat yang lebih berpengaruh pada abad ketujuh belas.

Bagaimana pandangan Descartes yang berpengaruh terhadap perkembangan psikologi dan bagaimana pula pengaruhnya? Apa gagasan Descartes yang dikritik kalangan empirisis tetapi justru menjadi pemantik bagi lahirnya ilmu baru: psikologi? Pertanyaan-pertanyaan tersebut akan dibahas pada subbab berikutnya.

\section{c. Sumbangsih Descartes dalam Perkembangan Psikologi}

Rene Descartes lahir pada tanggal 31 Maret 1596 sebagai anak ketiga dari Joachim Descartes dan Jeanne Brochard yang masih hidup (Clarke, 2006: 9). la dilahirkan dalam keluarga ahli hukum yang kaya dan mulai mengkonsolidasikan posisi sosialnya dengan mengabdi pada kerajaan Prancis. Descartes telah menjadi yatim piatu sejak usia satu tahun dua bulan karena kematian ayah dan ibunya yang telah lama meninggalkan rumah. Kondisi pada saat lahir dan masa kecilnya memberi kesan yang mendalam pada Descartes.

Latar belakang pemikiran Descartes adalah kritik terhadap pemikiran Skolastik. Pemikiran skolastik berkembang pada abad pertengahan sekitar tahun 1200-an sampai 1400-an M melalui para filsuf yang kembali mempelajari dan mengolah pemikiran Aristoteles. Kritik utama Descartes terhadap filsafat skolastik adalah argument yang premis-premisnya dilandaskan pada otoritas intelektual, yakni pemikiran Aristoteles, dan bukan pada argumentasi rasional (Ramsperger, 1961: 217). Francis Bacon (1220-1292) yang dipengaruhi sangat kuat oleh pemikiran Aristoteles, sejak awal telah menekankan bahwa pengetahuan tentang dunia haruslah diperoleh dari pengamatan langsung dan eksperimen. Descartes menyatakan bahwa pengetahuan yang sesungguhnya hanya dapat diperoleh dengan menggunakan akal budi. Panca indera tidak akan pernah dapat memberikan fondasi yang kuat atas pengetahuan karena pengetahuan tersebut terlalu mudah untuk disangkal keabsahannya.

Descartes memulai karir intelektualnya pada 1618-1619, berkarya dalam persoalan matematika dan "matematika fisika" (hydrostatics dan tubuh yang jatuh). Karya awalnya berupa teknik matematika yang membuat analisis geometri menjadi mungkin, dan mendasari pengenalan koordinat Cartesius pada abad ke-19 (Hattfield, 2009: 6-7). la berusaha membuat metode umum untuk memecahkan segala jenis masalah berdasarkan penalaran yang ditemukan dalam matematika selama periode 1620-an. la meninggalkan proyek ini dan buku yang sedang ditulisnya, "Rules for The Direction of The Mind", pada akhir 1620-an untuk memulai sebuah proyek ambisius bagi fisika baru yang komprehensif. Fisika baru ini melibatkan konsepsi ulang mendasar tentang materi sebagai bukan apa-apa kecuali ekstensi geometris yang terbuka tanpa prinsip-prinsip aktif dan "kualitas nyata" fisika Aristotelian. 
Descartes (1991: 40) bertujuan untuk menjelaskan semua fenomena alam material dengan membandingkan materi dan gerak sendiri-sendiri. Fisika barunya ini untuk menutupi topik yang ditemukan dalam fisika Aristotelian dan lainnya, termasuk formasi tata surya dan bumi, sifat-sifat mineral dan jenis alam anorganik lainnya, asal dan sifat tumbuhan dan hewan, tubuh manusia, jiwa manusia, dan hubungan mereka (Descartes, 1985: 131-41). Descartes tidak mempublikasikan risalah ini dalam hidupnya dan ketika dia meninggal hanya dua bagian yang masih bertahan yaitu Treatise on Light, karyanya tentang fisika umum alam anorganik, dan Treatise on Man, risalahnya tentang fisiologi dan perilaku manusia dan hewan. Naskah Perancis asli pertama kali diterbitkan pada tahun 1664 .

Descartes (1991: 22) juga mengajukan beberapa wawasan metafisik tentang Tuhan dan jiwa pada saat bersamaan ia mulai berkarya pada fisika barunya. la menguraikan konsep baru yang revolusioner tentang materi dan pikiran pada 1629-1630. Konsep baru yang radikal ia uraikan dalam "Discourse on the Method" 1637, terungkap dalam "Meditations on First Philosophy" pada 1641, dan digunakan untuk mengembangkan fisika barunya dalam "Principles of Philosophy" pada 1644, dan "Passions of the Soul" 1649, berimplikasi tidak hanya pada fisika yang dipahami sebagai ilmu alam secara umum, tetapi juga untuk subbidang fisiologi dan psikologi, serta untuk metafisika pikiran dan teori pengetahuan (Hattfield 2009: 7).

Bertrand Russsel (2002:342) menyatakan bahwa Descartes merupakan pembuka bagi filsafat modern. Bukunya "Meditations on First Philosophy" pada 1641 memberi sumbangan cukup besar dalam kemajuan ilmu dan peradaban manusia. Oleh karena itu, Descartes dikenal sebagai bapak filsafat modern. Descartes menulis bukunya ketika ilmu masih dalam bentuk embrio. Fisika, kimia, dan biologi, belum berdiri sebagai displin terpisah seperti sekarang. Penemuan-penemuan besar di bidang-bidang tersebut baru terjadi beberapa abad setelah masa hidup Descartes.

Tujuan utama Descartes adalah merumuskan suatu metode untuk memperoleh pengetahuan yang valid, serta merumuskan suatu kriteria yang jelas dan terpilah-pilah tentang pengetahuan (Ramsperger, 1961:217). la merefleksikan problem skeptisisme yaitu keraguan bahwa manusia dapat mengetahui sesuatu di dalam realitas. la menggunakan keraguan ini sebagai metode, dan berupaya melampauinya untuk sampai pada pengetahuan yang paling hakiki. la merefleksikan hakekat dari persepsi manusia, dan peran persepsi itu bagi pembentukan pengetahuan. la juga merefleksikan tentang diri (self), dan dengan begitu membuka kemungkinan untuk merefleksikan lebih jauh tentang identitas personal, subjektifitas, kebebasan, kehendak, dan sebagainya. la juga menulis tentang Tuhan, dan berupaya membuktikan keberadaannya secara logis. Minat yang beragam dari Descartes ini nantinya masing-masing akan berkembang menjadi cabang-cabang lainnya di dalam filsafat dan ilmu.

Metode merupakan fokus Descartes dalam awal karya filsafatnya. Karyanya tentang metode yang diterbitkan pertama kali ialah "Discourse de la Method". Bagian kedua buku itu menyatakan bahwa metode memiliki empat aturan (Copleston, 1971: 65). (1) Jangan pernah menerima apapun sebagai kebenaran jika tidak memiliki pengetahuan yang pasti tentang kebenarannya, hal ini berarti metode harus berhati-hati untuk menghindari kesimpulan tergesagesa dan prasangka. (2) Membagi setiap kesulitan dan memeriksa ke sebanyak mungkin bagianbagiannya. (3) Mengarahkan pikiran secara tertib, dengan memulai pada objek yang paling sederhana dan paling mudah diketahui secara perlahan-lahan sampai pada pengetahuan yang paling kompleks. (4) Untuk membuat enumerasi searah lengkap dan laporan secara komprehensif, harus yakin bahwa tidak suatu pun yang tertinggal.

Descartes telah meletakkan pondasi pada gerak modernisasi sains, tetapi bagaimana hubungannya dengan perkembangan psikologi? Schultz (2014: 54) menyatakan bahwa karya Descates menjadi katalis bagi banyak tren yang akan bertemu di dalam psikologi modern. Sumbangsih Descartes dalam perkembangan psikologi antara lain: (1) Konsepsi mekanisme; (2) Teori aksi refleks; (3) Interaksi pikiran-tubuh; (4) Spekulasi tentang fungsi-fungsi mental di otak; (5) Doktrin ide-ide bawaan.

Konsepsi Descartes tentang 'jiwa atau pikiran' berangkat dari teori yang lazim diterima (Hattfield, 2009: 7). Jiwa sebagai bentuk tubuh manusia tidak dapat eksis pada dirinya sendiri, keberadaannya lebih dari tubuh manusia, dapat menyatu dengan "tubuh manusia" tanpa menginformasikan kehadiran jiwa. Berbagai kekuatan jiwa terlibat secara langsung dalam mengarahkan karakteristik aktivitas semua organ tubuh seperti: organ-organ vital, indra, 
termasuk kehadiran langsung kekuatan sensorik dalam organ-organ indera dan saraf, otak yang merupakan lokus dari akal sehat dan kekuatan kognitif.

Descartes membayangkan pikiran dan tubuh sebagai substansi yang berbeda, yang berarti bahwa masing-masing adalah substansi yang mampu berdiri sendiri tanpa yang lain (Hattfield, 2009: 8). Dia memberikan dua kekuatan dasar pikiran: kecerdasan dan kehendak. Dia menjelaskan operasi tubuh dari organ indera bersifat mekanis murni. Otak, dalam persepsi indera, mempengaruhi pikiran (kekuatan intelektual) dengan cara yang menghasilkan sebuah pengalaman sadar. Descartes (1984: 114) lebih memilih istilah "pikiran" dari pada "jiwa" dalam konteks filosofis.

Descartes memutuskan hubungan dengan teori kognisi Aristotelian yang beranggapan bahwa akal tergantung pada isinya (objek-objek pemikiran) atau pada materi yang disediakan oleh indera (Hattfield 2009: 8). Oleh karena itu, Aristotelian beranggapa tidak ada pemikiran tanpa gambar, hal-hal imaterial seperti Tuhan atau malaikat samar-samar dipahami oleh analogi dengan hal-hal materi yang dapat dicitrakan. Descartes (1984: 50-51) menyatakan bahwa tindakan tertinggi intelektualitas, persepsi tentang esensi dari hal-hal yang "jelas dan terpilah" ("clear and distinct"), terjadi melalui tindakan intelektual yang tidak memerlukan atau melibatkan gambar.

Descartes mengomentari kedudukan basis empiris pengetahuan dasar yang dibayangkan oleh Aristotelian. Descartes mengemukakan bahwa kecerdasan manusia ditetapkan dengan pangkal ide-ide bawaan (innate ideas) yang telah disesuaikan (oleh Tuhan) pada esensi sesungguhnya dari jenis dasar hal-hal di dunia. Manusia memiliki ide-ide bawaan (innate ideas) tentang pikiran (immaterial), tentang materi (sebagai keluasan), dan tentang Tuhan (sebagai keberadaan tak terbatas).

Teori kognisi intelektual Descartes menunjukkan kemiripan dengan tradisi Platonis, tetapi dengan beberapa perbedaan (Hattfield, 2009: 8). Platonis beranggapan bahwa pikiran menangkap "Bentuk-Bentuk extramental" ketika mengetahui esensi dari hal-hal, sedangkan Descartes menganggap bahwa isi fundamental kognisi intelektual adalah bawaan (innate) pada pikiran individu. Platonis juga memandang rendah pengetahuan sensorik, sedangkan Descartes menganggap bahwa indera dapat menyediakan data penting bagi pengetahuan ilmiah jika isi data ditafsirkan dengan benar menggunakan pengetahuan metafisik yang diperoleh dengan menggunakan kecerdasan itu sendiri.

Konsepsi baru Descartes tentang "pikiran dan materi" menunjukkan bahwa ia mendistribusikan ulang fungsi jiwa menurut Aristotelian melalui pembedaan pikiran-tubuh (Hattfield, 2009: 8). Descartes menempatkan pada pikiran beberapa fungsi psikologis penting, termasuk kesadaran, kehendak, penalaran umum, dan penggunaan bahasa bermakna (meaningful). Dia percaya bahwa fungsi-fungsi ini tidak dapat dijelaskan melalui materi dalam gerakan.

Descartes mengembangkan psikologi mekanistik tanpa pikiran (mindless mechanistic psychology) untuk menggantikan bagian dari psikologi Aristotelian. Descartes (1984: 161) mengklaim bahwa ia dapat menjelaskan banyak perilaku manusia yang tidak melibatkan pikiran. Hal inilah yang kemudian dikenal dengan teori aksi refleks tubuh dalam psikologi.

\section{Kesimpulan}

Pemikiran Rene Descartes telah mengalami evolusi sehingga kemudian muncul sebuah ilmu baru yang saat ini dikenal dengan nama psikologi. Rene Descartes telah meletakkan prinsipprinsip tentang metode yang melandasi penyelidikan ilmiah setelahnya untuk mengilhami pemikir dan ilmuwan berikutnya menghasilkan ilmu-ilmu baru termasuk psikologi. Pemikiran Rene Descartes tentang hubungan pikiran dan tubuh menjadi stimulus pada ilmuwan di kemudian hari untuk menyelidiki dan membuktikan lebih lanjut sehingga kemudian terspesialisasi menjadi batasan objek penyelidikan psikologi.

Descartes memperkenalkan ide mekanisme yang diterapkan pada tubuh manusia yang kemudian menyebar dan tak terhindarkan untuk diterapkan pada pikiran manusia yang kemudian berkembang menjadi psikologi. Beberapa spekulasi Descartes pada masanya seperti interaksi tubuh-pikiran, fungsi-fungsi mental dalam otak, aksi reflek tubuh, telah mengetuk pintu penyelidikan lebih lanjut yang menjadi basis perkembangan psikologi. Dengan demikian, dapat diakui andil Rene Descartes dalam modernisasi ilmu merupakan sebuah pijakan (milestone) dan 
kondisi pendukung (neccessary condition) bagi munculnya psikologi dua abad kemudian. Hal itu dapat menjadi rujukan dan spirit pada ilmuwan saat ini dalam upaya penyelidikan dan pengembangan ilmu-ilmu baru ke depannya.

\section{DAFTAR PUSTAKA}

Adian, D.G. and Lubis, A.Y., 2011. Pengantar Filsafat Ilmu Pengetahuan: Dari David Hume sampai Thomas Kuhn. Jakarta: Penerbit Koekoesan.

Clarke, D.M., 2006. Descartes: A Biography. Cambridge: Cambridge University Press.

Copleston, F. 1971. A History of Philosophy Volume IV Descartes to Leibniz. London: Searh Press.

Descartes, Rene, 1984, Philosophical Writings of Descartes, vol. 2, trans. J. Cottingham, R. Stoothoff, and D. Murdoch,Cambridge: Cambridge University Press. (Includes the Meditations with Objections and Replies, originally published in 1641). , 1985, Philosophical Writings of Descartes, vol. 1, trans. J. Cottingham, R. Stoothoff, and D. Murdoch, Cambridge: Cambridge University Press. (Contains the Rules, Discourse, Passions, and selections from the Principles, Dioptrics, and other scientific works.) , 1991, Philosophical Writings of Descartes, vol. 3: The Correspondence, trans. J. Cottingham, R. Stoothoff, D. Murdoch, and A. Kenny, Cambridge: Cambridge University Press.

Hatfield, G. 2009. "Rationalist Roots of Modern Psychology”. Dalam Symons, J., Palco, C. The Routledge Companion To The Philosophy of Psychology. New York: Routledge.

Jahja, Y., 2011. Psikologi Perkembangan. Yogyakarta: Kencana.

Kaelan, 2002. Metodologi Penelitian Kualitatif Bidang Filsafat, Yogyakarta: Penerbit Paradigma.

Lapointe, Francois H. (1972) "Who Originated The Term 'Psychology'?" Journal of the History of the Behavioral Sciences 8: 328-35.

Muslih, M., 2004. Filsafat IImu; Kajian atas Asumsi Dasar, Paradigma, dan Kerangka Teori IImu Pengetahuan. Yogyakarta: LESFI.

Ramsperger, A. G. 1961. "Early Modern Rationalism" dalam A History of Philosophycal System. Ferm, V (Ed.). New Jersey: Littlefield Adams and C. petterson.

Raymond, M. 2009. "Empiricist Roots of Modern Psychology". Dalam Symons, J., Palco, C. The Routledge Companion To The Philosophy of Psychology. New York: Routledge.

Russel, B. 2002. History of western hilosophy and its Connection With Political and Social Circumstances from The earliest Times to The Present Day. Kamdani (Ed.). Yogyakarta: Pustaka Pelajar.

Schultz, Duanel P., Sydney Ellen Schultz. 2014, Sejarah Psikologi Modern. Terj: Lita Hardian. Bandung: Nusa Media.

Van Melsen, A.G.M. and Nugroho, A.A., 1982. Ilmu Pengetahuan dan Tanggung Jawab Kita. Terjemahan: K. Bartens, Jakarta: Penerbit Gramedia.

Weiten, W., 2017. Psychology: Themes and Variations. Boston: Cengage Learning. 